Lichenologist 11(3): 271-281 (1979)

\title{
THE CHEMISTRY OF PSEUDOCYPHELLARIA IMPRESSA S. LAT. IN NEW ZEALAND
}

\author{
A. L. WILKINS ${ }^{\star}$ and P. W. JAMES $\uparrow$
}

\begin{abstract}
Introduction
As part of a detailed study of the nomenclature and taxonomy of the New Zealand species of Pseudocyphellaria it has been noted that the chemistry of the $P$. impressa (Hook \& Taylor) Vainio aggregate, that is species with a markedly faveolate (honeycomb-like) upper surface and a green algal phycobiont, is particularly complex. The 45 lichen substances detected fall into four distinct groupings, here designated as 'Codings'. The aim of this contribution is to investigate suitable methods for revealing this chemical assemblage by t.l.c. and, as far as is currently possible, to identify the range of substances. No conscious attempt is made to assign the four chemical Codings to particular taxa or species groupings; the taxonomy of the group will be discussed elsewhere. The four Codings proved to be remarkably uniform and constant considering the range and number of substances involved; such variation that occurred was only in the presence and concentration of accessory substances.

Although this work only concerns New Zealand material, similar patterns occur in related taxa of the group present in southern South America, south-east Australia and Tasmania.
\end{abstract}

\section{Methods and Material}

T.1.c. analyses of cold acetone extractives of small fragments detached from each thallus were carried out on Merck silica gel $60 \mathrm{~F}_{254}$ using three solvent systems: toluene (90): dioxan (25): acetic acid (4) (TDA): hexane (125): ether (90): formic acid (20) (HEF) (Culberson and Kristinsson, 1970; Culberson, 1972; Menlove, 1974); and hexane (1): ether (3) (HE) for the resolution of the full range of detectable metabolites. The TDA and HEF assays were run over a distance of $15 \mathrm{~cm}$, whilst each $\mathrm{HE}$ assay was successively run three times consecutively over a repeated distance of $12 \mathrm{~cm}$ allowing the solvent to evaporate before the second and third re-run. Two directional chromatography, as outlined by Maass (1975), was utilized using TDA solvent for the first axis and HEF solvent for the second.

The resulting assays were partially visualized by examination and marking in daylight (for pigments) and under u.v. at 254 and $350 \mathrm{~m} \mu$. Following this, the plates were sprayed with $10 \%$ aqueous sulphuric acid and charred in an oven at $110^{\circ} \mathrm{C}$ for up to $10 \mathrm{~min}$ to ensure full visualization. After charring the specific colours of the substances, both in daylight and under u.v. $(350 \mathrm{~m} \mu)$ were noted. Study of prepared plates under u.v. was found to give valuable additional information and is, in our estimation, an aspect in lichen chromatography which has been neglected. In the case of the species aggregate studied here the major groups of constituents were clearly recognizable: the mono- and dimethylated di- and tridepsides

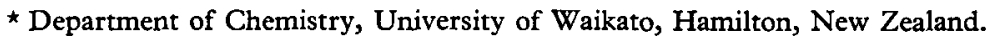

+ Department of Botany, British Museum (Natural History), Cromwell Road, London SW7 5BD.
} 
appeared as pale straw-yellow to orange-yellow spots and are situated rather high on all the one-directional assays; under u.v. $(350 \mathrm{m \mu})$ these spots appeared dark with a distinctive green or yellow-green cast. The triterpenoids, which are revealed only after charring, give purple or mauve spots appearing as distinctive pink-orange spots under u.v. (350 mu) after charring. Depsidones of the stictic acid aggregate appear as yellow to orange spots appearing dull red or black and opaque under u.v. $(350 \mathrm{m \mu})$. Likewise, the spots of physciosporin and methyl virensate are pale or dark grey in daylight becoming black and more or less dense under u.v. The pigments appeared as pale to deep yellow spots before development of the plate after the solvent run.

Identification of the substances was achieved, in the main, by comparative assays with specimens of named species with known products. In the case of the triterpenoids, pure samples of known identity were also used for comparative purposes.

The number of samples, all from New Zealand, Campbell Island, and the Auckland Islands, used in our survey were: Coding A (46 specimens), Coding B (54), Coding C (124), and Coding D (68). All are deposited in the British Museum (Natural History) (BM) and have been annotated accordingly. Type specimens studied mentioned in the text are indicated by ' $(T)$ ', after the species epithets.

\section{Compendium of metabolites}

The numbers alloted to metabolites below are used in Figs 1-5.

\section{A. Depsides}

1. Methyl evernate.

6. Methyl gyrophorate.

2. Tenuiorin.

3. Unknown substance.

7. Unknown substance.

4. Unknown substance.

8. Unknown substance.

5. Methyl lecanorate.

9. Evernic acid.

10. Gyrophoric acid.

(a)<smiles>Cc1cc(OC(=O)c2c(C)cc([18O])cc2O)cc(O)c1C(=O)O</smiles>

$\begin{array}{lll} & \mathrm{R}^{1} & \mathrm{R}^{2} \\ 1 & \mathrm{CH}_{3} & \mathrm{CH}_{3} \\ 5 & \mathrm{CH}_{3} & \mathrm{H} \\ 9 & \mathrm{H} & \mathrm{CH}_{3}\end{array}$

(b)<smiles>Cc1cc(OC(=O)c2c(C)cc(OC(=O)c3cc([18O])cc(O)c3C(=O)O)cc2O)cc(O)c1C(=O)O</smiles>

$\begin{array}{rll} & \mathrm{R}^{1} & \mathrm{R}^{2} \\ 2 & \mathrm{CH}_{3} & \mathrm{CH}_{3} \\ 6 & \mathrm{CH}_{3} & \mathrm{H} \\ 10 & \mathrm{H} & \mathrm{H}\end{array}$




\section{B. Triterpenoids}

11. $7 \beta$-Acetoxyhopan-22-ol.

12. Hopane-7 $\beta, 22$-diol.

13. Hopane-15 $\alpha, 22$-diol.

14. Hopane- $6 \alpha, 7 \beta, 22$-triol.

15. Hopane- $6 \alpha, 22$-diol(zeorin).

16. Leucotylin derivative; probably $6 \alpha, 16 \beta$-diacetoxyhopan-22-ol.

17. Leucotylin derivative; probably $6 \alpha$-acetoxyhopane-16 $\beta, 22$-diol.

18. Leucotylin derivative; probably $6 \alpha$-acetoxy-22-hydroxyhopan-23-oic acid.
19. Leucotylin derivative; probably $6 \alpha$-22-dihydroxyhopan-23-oic acid.

20. $7 \beta$-Acetoxyhopane- $6 \alpha, 22$-diol.

21. $6 \alpha$, Acetoxyhopane-7 $\beta, 22-$ diol.

22. Unknown triterpenoid.

23. Unknown triterpenoid.

24. Unknown triterpenoid.

25. Unknown triterpenoid.

26. Unknown triterpenoid.

27. Unknown triterpenoid.

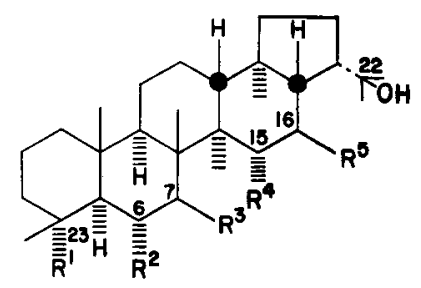

$\begin{array}{llllll} & \mathrm{R}^{1} & \mathrm{R}^{2} & \mathrm{R}^{3} & \mathrm{R}^{4} & \mathrm{R}^{5} \\ 11 & \mathrm{CH}_{3} & \mathrm{H} & \mathrm{OAc} & \mathrm{H} & \mathrm{H} \\ 12 & \mathrm{CH}_{3} & \mathrm{H} & \mathrm{OH} & \mathrm{H} & \mathrm{H} \\ 13 & \mathrm{CH}_{3} & \mathrm{H} & \mathrm{H} & \mathrm{OH} & \mathrm{H} \\ 14 & \mathrm{CH}_{3} & \mathrm{OH} & \mathrm{OH} & \mathrm{H} & \mathrm{H} \\ 15 & \mathrm{CH}_{3} & \mathrm{OH} & \mathrm{H} & \mathrm{H} & \mathrm{H} \\ 16 & \mathrm{CH}_{3} & \mathrm{OAc} & \mathrm{H} & \mathrm{H} & \mathrm{OAc} \\ 17 & \mathrm{CH}_{3} & \mathrm{OAc} & \mathrm{H} & \mathrm{H} & \mathrm{OH} \\ 18 & \mathrm{COOH} & \mathrm{OAc} & \mathrm{H} & \mathrm{H} & \mathrm{H} \\ 19 & \mathrm{COOH} & \mathrm{OH} & \mathrm{H} & \mathrm{H} & \mathrm{H} \\ 20 & \mathrm{CH}_{3} & \mathrm{OH} & \mathrm{OAc} & \mathrm{H} & \mathrm{H} \\ 21 & \mathrm{CH}_{3} & \mathrm{OAc} & \mathrm{OH} & \mathrm{H} & \mathrm{H}\end{array}$

\section{Depsidones}

28. Methyl virensate (granulatin).

29. Physciosporin (5-chloromethylvirensate, chlorogranulatin).<smiles>[2H]c1c(C)c(O)c(C=O)c(Oc2c(C)c(C)c(O)c(C(=O)O)c2C)c1C</smiles> 
30. Norstictic acid.

31. Stictic acid.

32. Unknown substance.

33. Unknown substance.

34. Unknown substance.
35. Constictic acid.

36. Unknown substance.

37. Unknown substance.

38. Unknown substance.<smiles>Cc1cc(O)c(C)c2c1OC(=O)c1c(c3c(c(O)c1-c1ccccc1)C(O)OC3=O)O2</smiles>

$\begin{array}{lll} & \mathbf{R}^{1} & \mathbf{R}^{2} \\ 30 & \mathbf{H} & \mathbf{H} \\ 31 & \mathrm{CH}_{3} & \mathbf{H} \\ 35 & \mathrm{CH}_{3} & \mathrm{OH}\end{array}$

D. Pulvinic acid derivatives

39. Pulvinic dilactone.

40. Calycin.

41. Pulvinic acid.

E. Unknown substances (? Sterols)

42. Unknown substance.

43. Unknown substance.

44. Unknown substance.

45. Unknown substance.

\section{Results and Discussion}

\section{Coding A}

Corbett and Young $(1966 a, b)$ isolated two triterpenoids from material identified as Pseudocyphellaria billardieri (Sticta billardieri). On t.l.c. plates the faster moving of the two substances was identified as 7 $\beta$-acetoxyhopan-22-ol (11), whilst the slower moving is hopane-15a,22-diol (13). In addition we have also noted the presence of a third triterpenoid of intermediate $R_{\mathrm{F}}$ value. This substance, which is only present in minor and variable amounts, is hopane-7 $\beta, 22$-diol (12).

The same combination of triterpenoids (11-13) also occurs in a number of other southern hemisphere species of Pseudocyphellaria, including the New Zealand taxa $P$. homoeophylla $(\mathrm{T}), P$. delisea (including type material of $P$. glabra, $P$. chloroleuca and $P$. delisea), $P$. intricata (Coppins and James, 1979), P. psilophylla (T), $P$. fragillima and $P$. coriacea $(\mathrm{T})$. With the exception of $P$. coriacea, the triterpenoid compliment in these species is accompanied by other lichen substances, either constituents of the stictic acid aggregate, or di- and/or tridepsides of the lecanoric and gyrophoric acid complexes.

Pseudocyphellaria billardieri, as understood here, appears to be a clearly defined entity, at least in New Zealand, morphologically distinguished by the presence of broad, lunate-lacunose primary faveolations on the upper surface; the pale, often sparsely tomentose or nearly naked, lower surface; and the red-brown (especially 
when wet), mainly marginal apothecia. Chemically this species appears to have little affinity with the other taxa allied to $P$. impressa s. lat. discussed here and may prove on further investigation to be unrelated.

Both Pseudocyphellaria homoeophylla and its polymorphic, sorediate-isidiateschizoid counterpart $P$. delisea have occasionally been misidentified as either $P$. billardieri or $P$. impressa. Although the former two species contain the same triterpenoids as $P$. billardieri, substances of the stictic acid complex (norstictic acid, stictic and constictic acid and several unknown accessory substances) are invariably present. Although the $P$. impressa group contains the stictic acid complex, the combination of triterpenoids in this aggregate is always different (see below) from that in P. billardieri, P. homoeophylla and P. delisea.

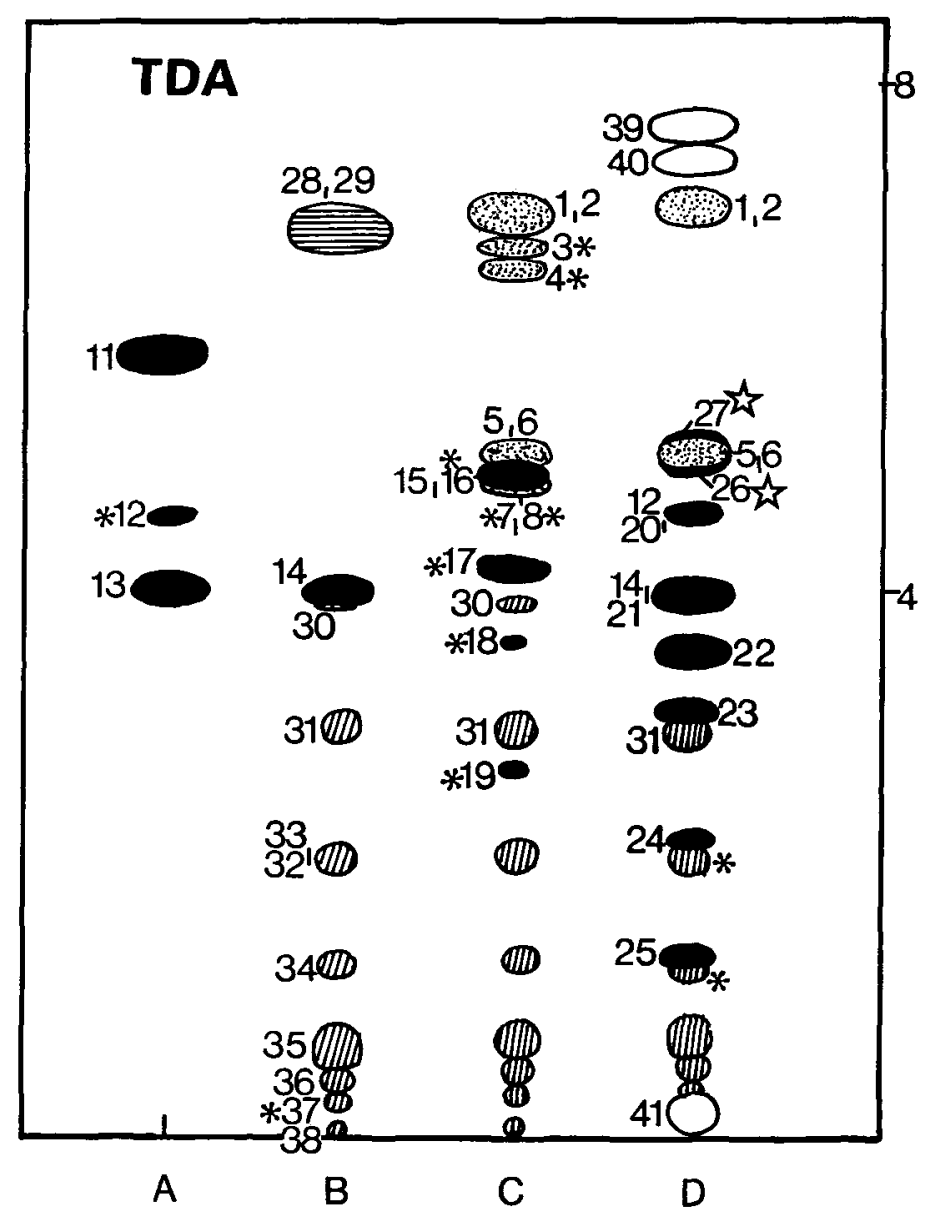

FIG. 1. Codings A-D in TDA; horizontal shading=physciosporin and methyl virensate; vertical shading $=$ depsidones of the stictic acid complex; spotted $=$ mono and dimethylated di- and tridepsides; solid =triterpenoids; unshaded = pigments; asterisk $=$ accessory ( \pm substances); open star $=$ position of an occluded metabolite not visible on this plate. See text for details. The figures refer to metabolites listed on pp. 272-274. 


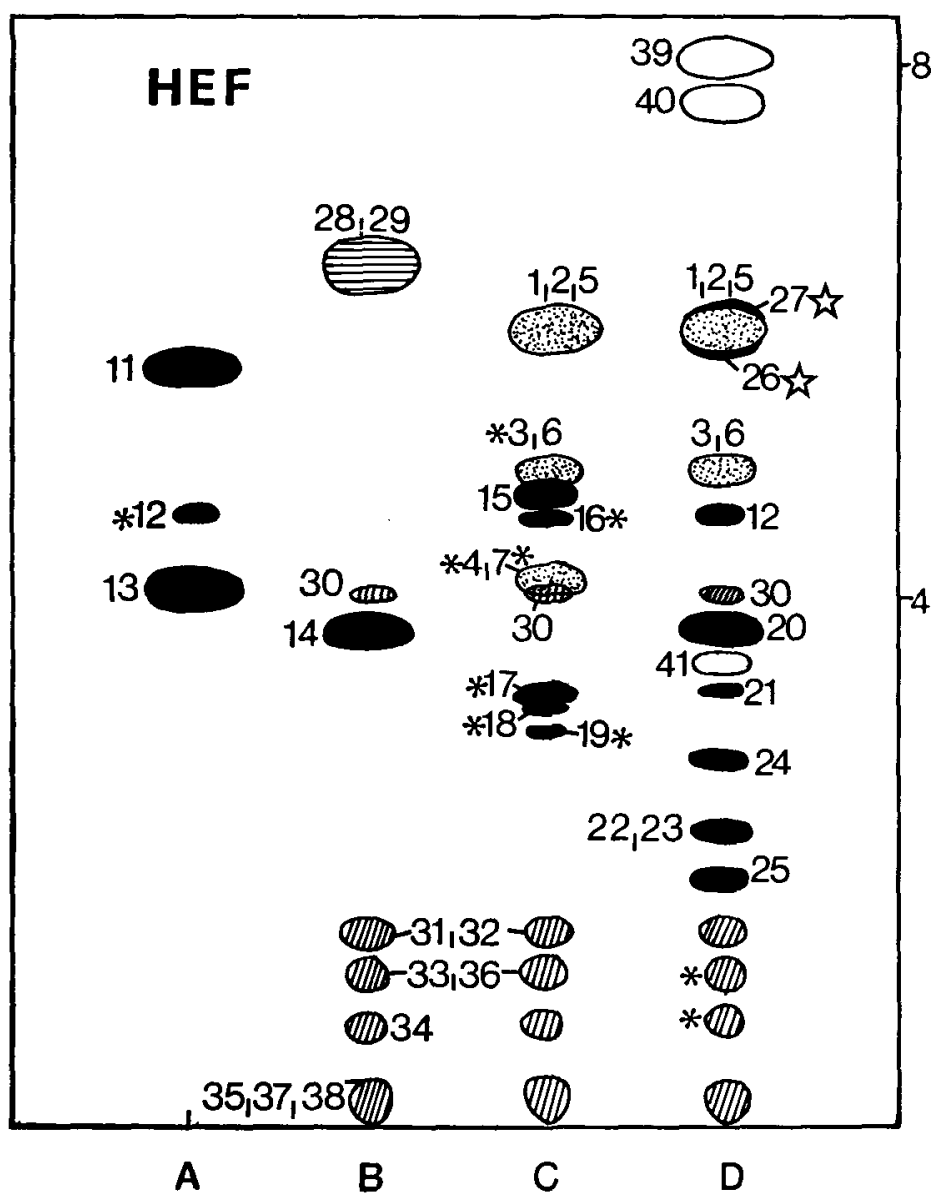

FIG. 2. Codings A-D in HEF. Legend otherwise as for Fig. 1.

\section{Coding B}

The only triterpenoid which occurs in this grouping is hopane-6 $\alpha, 7 \beta, 22-\operatorname{triol}(14)$. This triol, the structure of which has recently been revised (Corbett and Wilkins, 1977), was first isolated from Pseudocyphellaria mougeotiana (Sticta crocata) by Corbett and Cumming (1971). Other New Zealand species of Pseudocyphellaria which contain this triterpenoid are $P$.granulata $(\mathrm{T}), P$. hookeri $(\mathrm{T}), P$. montagnei $(\mathrm{T})$ and $P$. australiensis $(\mathrm{T})$. Moreover, the substance designated crocatin by Maass (1975), isolated from $P$. crocata, has been demonstrated by us to be identical with this triterpenoid. In the TDA and $\mathrm{HE}(\times 3)$ solvent systems the t.l.c. $\boldsymbol{R}_{\mathrm{F}}$ value of hopane-6 $\alpha, 7 \beta, 22$-triol (14) almost corresponds to that of hopane-15 $\alpha, 22$-diol (13) as seen in Coding A (Fig. 1); however, a clear distinction between the two substances can be obtained in the HEF solvent system (see Fig. 2). That this triol (14) has a t.l.c. $R_{\mathrm{F}}$ value more akin to that of a diol can be attributed to intramolecular hydrogen bonding within the $6 \alpha, 7 \beta$-diol system which significantly reduces its net external 
polarity thus resulting in a more rapid rate of travel on silica gel chromatography plates than would otherwise be expected from a triol.

The identification and analyses of the structures of the two depsidones $(28,29)$ have been elucidated: 28 is methyl virensate (Renner et al., 1978) which is the same as granulatin of Goh and Wilkins (1979) published subsequently. Substance 29 corresponds to physciosporin of Maass et al. (1977), 5-chloromethyl virensate (Renner et al., 1978) and chlorogranulatin (Goh and Wilkins, 1979). Huneck et al.

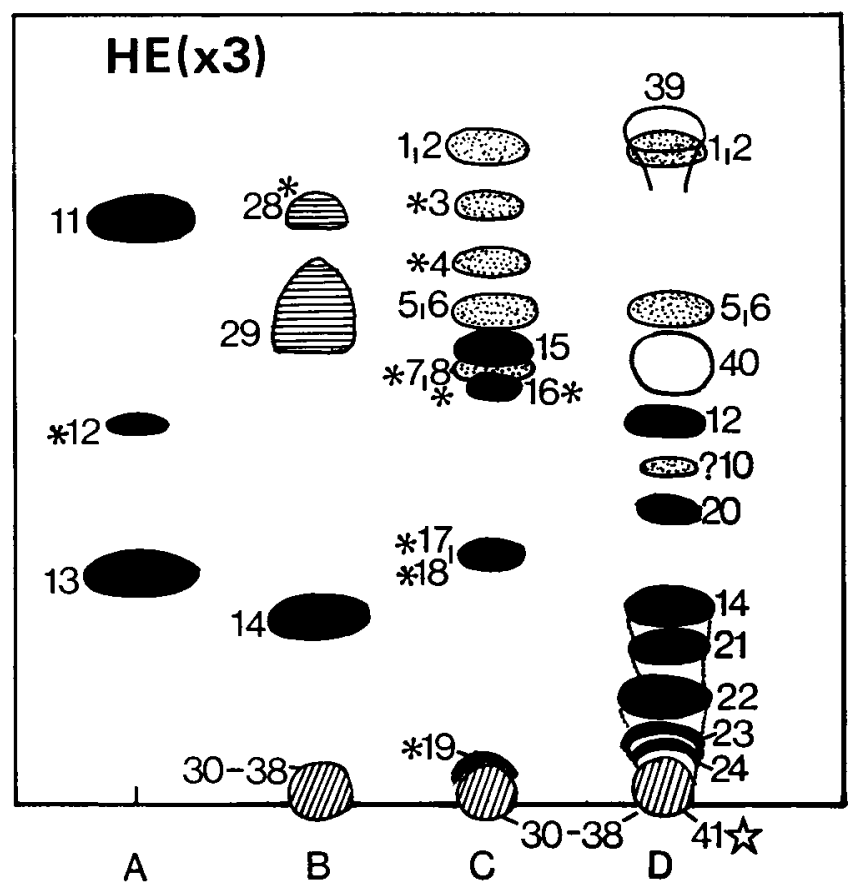

FIg. 3. Codings A-D in hexane: ether ( $\times 3)$. Legend otherwise as for Fig. 1.

(1973) and Imshaug (1978) have confused this pair of compounds with pannarin. Although methyl virensate (28) and physciosperin (29) have identical t.l.c. $R_{\mathrm{F}}$ values in the TDA and HEF solvent systems, they are readily separated by the successive triple running of the plate in the HE solvent before analysis and charring (Fig. 3). This solvent system is also useful for the separation of the related depsides atranorin and chloroatranorin, neither of which, however, has been demonstrated in any of the Pseudocyphellaria species under review.

Maass(1975)reported atranorin and chloroatranorin from an unlocalised gathering of $P$. crocata but we have been unable to verify this; these two substances are not present in the holotype (Lichen crocatus L., India, Koenig, LINN sheet no. 1273.137).

Constituents of the stictic acid aggregate (30-38) are also present in Ceding B and the entire combination of substances corresponds to that found in the sorediate 
species $P$.granulata $(\mathrm{T})$ and its possible non-sorediate counterpart, $P$. faveolata $(\mathrm{T})$, both of which also occur in southern South America.

\section{Coding C}

Constituents of three major metabolic pathways are present in this Coding. These are substances of the stictic acid complex, mono- and dimethylated di- and tridepsides, and triterpenoid compounds.

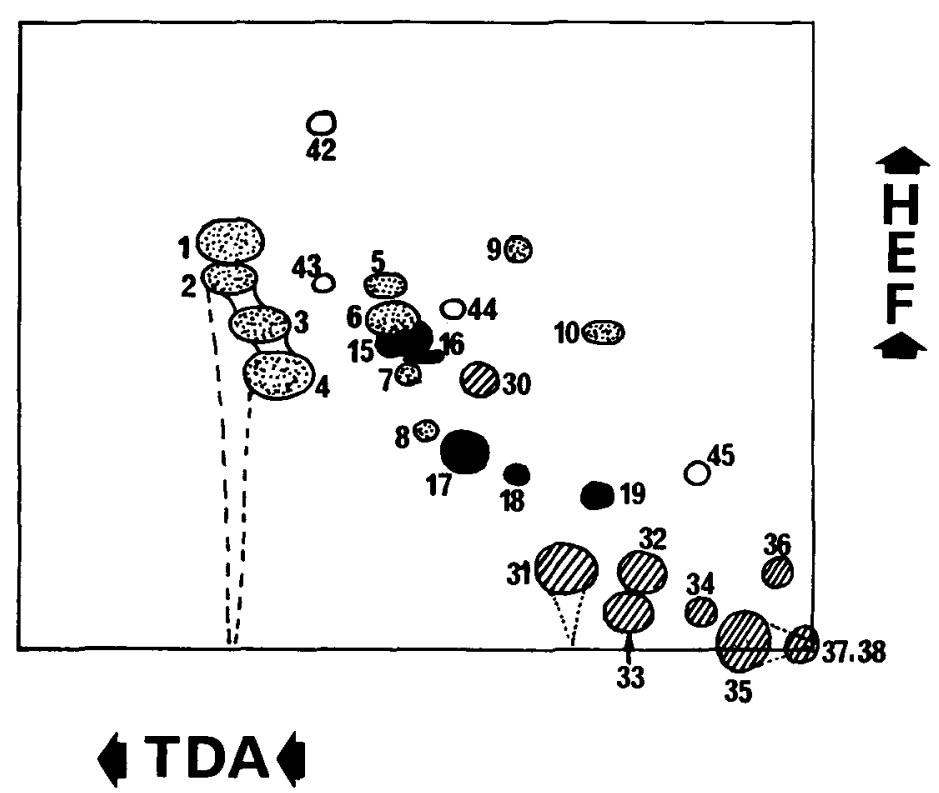

FIG. 4. Coding C, two directional assay, TDA (1) and HEF (2). Legend otherwise as for Fig. 1. (42-45 are possibly sterols.)

The presence of the triterpenoid hopane-6a,22-diol, otherwise called zeorin (15), has been confirmed by direct isolation (Ronaldson, 1977). In addition to this substance, we have detected small, variable quantities of up to four other triterpenoids corresponding to some of the constituents of Parmelia entotheiochroa (Yosioka et al., 1966). Although, by comparison, hopane-6 $\alpha, 16 \beta, 22$-triol (leucotylin) is not present among these minor additional triterpenoids, we have been able to identify the assemblage (16-19) as including $6 \alpha, 16 \beta$-diacetoxyhopan-22-ol, $6 \alpha$-acetoxyhopane16 $\beta, 22$-diol, $6 \alpha$-acetoxy-22-hydroxyhopan-23-oic acid, and 6a,22-dihydroxyhopan23-oic acid although the exact identity of each spot has not yet been established. These substances, together with leucotylin, are the main triterpenoid constituents of many species of Heterodermia (Kurokawa, 1973).

The identification of the di- and tridepside metabolites poses a difficult problem because of the confusingly similar and/or interchangeable t.l.c. $R_{\mathrm{F}}$ values. Because of this the depside metabolites in Codings $C$ and $D$ can neither be reliably identified 
by single one-directional assays in TDA or HEF solvent systems, nor in a triple run in $\mathrm{HE}$ solvent. Instead the application of the two dimensional assay, first used in Pseudocyphellaria by Maass (1975), overcomes this difficulty (see Figs 4-5).

By this approach we have been able to demonstrate (Fig. 4) the occurrence of methyl evernate (1), tenuiorin (2), methyl lecanorate (5), methyl gyrophorate (6), evernic acid (9) and gyrophoric acid (10); constituents $3,4,7$ and 8 are unknown depsides which do not appear to correspond to any of the di- and/or mono-methylated depsides described by Maass (1977) from Pseudocyphellaria crocata. The structure and nature of these substances is being investigated.

A number of other minor substances have also been detected, some of which may possibly be sterols (42-45).

\section{Coding D}

All the New Zealand specimens of the Pseudocyphellaria impressa aggregate with a white medulla and more or less pale yellow pseudocyphellae appear to have a common chemistry. This is in direct contrast with those species discussed here which have white pseudocyphellae and are demonstrated to belong to three different Codings (A, B, C). Of the four Codings, $\mathrm{D}$ is the most complex.

The yellow pigments in Coding $\mathrm{D}$ (Figs 2,5 ), mainly concentrated at and just below the surface of the pseudocyphellae, have been identified as pulvinic acid (41), pulvic lactone (39) and calycin (40). These substances appear to be ubiquitous in all Pseudocyphellaria species which have yellow pseudocyphellae and/or medullary tissue. Minor accessory substances accompany these three main pigments.

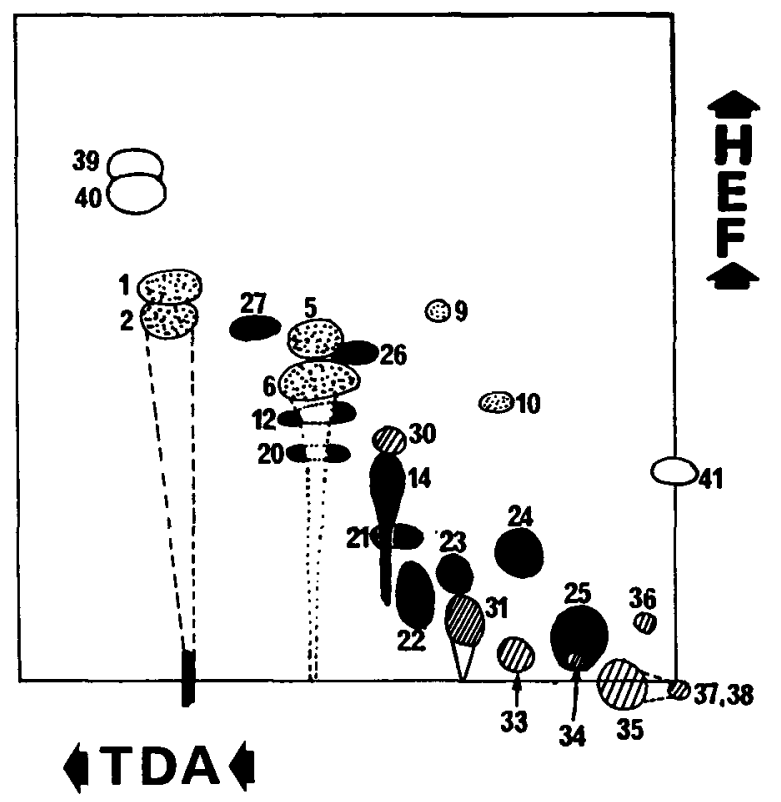

FIG. 5. Coding D, two directional assay, TDA (1) and HEF (2). Legend otherwise as for Fig. 1. 
Mono- and dimethylated di- and tridepsides are present in all the material examined. By two dimensional assays (see Fig. 5) these have been determined as methyl evernate (1), tenuiorin (2), methyl lecanorate (5) and methyl gyrophorate (6). The additional metabclites $(3,4,7,8)$ which occur in Coding $C$ are never present in Ccding D.

The stictic acid aggregate of substances is the same as that found in Codings $B$ and $\mathrm{C}$; as noted before, the reliable identification, at the simplest level, of the individual constituents of this aggregate is only possible by two dimensional assays.

Similarly, the reliable identification of the triterpenoid metabolites also requires a similar analysis since different pairs of substances, especially those related to the $6 \alpha, 7 \beta, 22$-triol (14) have coincidentally identical t.l.c. $R_{\mathrm{F}}$ values in the TDA and HEF solvent systems. Purified samples of the $7 \beta, 22-$ diol (12) and the two triol monoacetates $(20,21)$ for comparison were refined from extractives of Pseudocyphellaria crocata (Corbett and Cumming, 1971; Corbett and Wilkins, 1977). It seems that these accessory triterpenoids are confined to species of the genus which also have the yellow pigments calycin, pulvic lactone and pulvinic acid.

An additicnal group of up to six substances (22-27, best seen in Figs 1-2, 5), presumed from their colour on prepared plates after charring and under UV $(350 \mathrm{~m} \mu)$ to be triterpenoids, also occur with the aforementioned identified triterpenoids. The structure and identity of this second group has not been established and their relative intensity makes them difficult to assess for although the area covered by their spots on t.l.c. plates is often greater than those of the hopane triterpencids of established structure $(12,14,20,21)$, their relative quantities, as reflected by their faintness, would appear to be less.

The chemistry of two further species, Pseudocyphellaria hookeri and P. montagnei, is sometimes confused with Codings $B$ and $D$. The major metabolites of these two species are the triol, $6 \alpha, 7 \beta, 22$-triol (14), methyl evernate (1), tenuiorin (2), methyl lecanorate (5), and methyl gyrophorate (6) as well as the stictic acid aggregate. Thus these two species combine the triterpenoid of Coding B and the di- and tridepsides of Coding $\mathrm{D}$ but lack physciosporin and methyl virensate of Coding $\mathrm{B}$ and the pigments and minor accessory triterpencids of Coding $\mathrm{D}$.

\section{Summary}

Forty-five substances, arranged in four Codings, are distinguished in New Zealand material of Pseudocyphellaria impressa s. lat. Two dimensional t.l.c. proved of particular value in the resolution and recognition of the metabolites.

We are grateful to Dr D. J. Galloway for assistance in various ways.

\section{REFERENCES}

Coppins, B. J. and James, P. W. (1979) New or interesting British lichens IV. Licherologist 11: $139-179$.

Corbett, R. E. and Young, H. (1966a) Lichens and fungi. Part II. Isolation and structural elucidation of $7 \beta$-acetoxy-22-hydroxyhopane from Sticta billardieri Del. F. Chem. Soc. 1966c: $1556-1563$.

Corbett, R. E. and Young, H. (1966b) Lichens and fungi. Part III. Structural elucidation of 15a,22-dihydroxyhopane from Sticta billardieri Del. F. Chem. Soc. 1966c: 1564-1567. 
Corbett, R. E. and Cumming, S. D. (1971) Lichens and fungi. Part VII. Extractives from the lichens Sticta mougeotiana var. dissecta Del. F. Chem. Soc. 1971c: 955-960.

Corbett, R. E. and Wilkins, A. L. (1977) Lichens and fungi. Part XV. Revised structures of hopane triterpenoids isolated from the lichen Pseudocyphellaria mougeotiana. Austral. $\mathfrak{F}$. Chem. 30: 2329-2332.

Culberson, C. F. (1972) Improved conditions and new data for the identification of lichen products by a standardized thin-layer chromatographic method. F. Chromatogr. 72: 113-125.

Culberson, C. F. and Kristinsson, H. (1970) A standardized method for the identification of lichen products. $\mathcal{F}$. Chromatogr. 46: 85-93.

Goh, E. M. and Wilkins, A. L. (1979) Structures of the lichen depsidones granulatin and chlorogranulatin. F.C.S. Perkin I. 1979: in press.

Huneck, S., Redon, J. and Quilhot, W. (1973) Mitteilungen über Flechteninhaltsstoffe XCVII. Zur Phytochemie südamerikanischer Pseudocyphellariaceen. F. Hattori Bot. Lab. 37: 539-562.

Imshaug, H. A. (1978) Austral lichen populations. In Adaptations within Antarctic Ecosystems [Proceedings of the Third SCAR Symposium on Antarctic Biology.] (G. A. Llano, ed): 947-966. Washington: Smithsonian Institution.

Kurokawa, S. (1973) Supplementary notes on the genus Anaptychia. F. Hattori Bot. Lab. 37 : 563-607.

Maass, W. S. G. (1975) Lichen substances. V. Methylated derivatives of orsellinic acid, lecanoric acid, and gyrophoric acid from Pseudocyphellaria crocata. Can. 7. Bot. 53: 1031-1039.

Maass, W. S. G., McInnes, A. G., Smith, D. G. and Taylor, A. (1977) Lichen substances X. Physciosporin, a new chlorinated depsidone. Can. F. Chem. 55: 2839-2844.

Menlove, J. E. (1974) Thin-layer chromatography for the identification of lichen substances. Bull. Br. Lichen Soc. 34: 3-5.

Renner, B., Henssen, A. and Gerstner, E. (1979) Methylvirensat und 5-Chlor Methylvirensat aus Arten der Flechtengattung Pseudocyphellaria. Z. Naturforsch. 33c: 826-830.

Ronaldson, K. J. (1977) Structural studies of triterpenoids. M.Sc. thesis, University of Waikato.

Yosioka, I., Yamaki, M. and Kitagawa, I. (1966) On the triterpenic constituents of a lichen, Parmelia entotheiochroa Hue; zeorin, leucotylin, leucotylic acid, and five new related compounds. Chem. Pharm. Bull. (Tokyo) 14: 804-807. 
